\title{
The Puritan paradox: an annotated bibliography of Puritan and anti-Puritan New Zealand fiction, 1860- 1940. Part 2: reactions against Puritanism.
}

\author{
Kirstine Moffat
}

This bibliography springs from my examination of the literary, social, and cultural legacy of Puritanism in pre-1940 New Zealand. A brief overview of the aims and methodology of the thesis which embodies that study is provided here as a prelude to the bibliography.

The broad contention of my thesis is that Puritanism is a dominant social, cultural, and literary influence in New Zealand. This is supported by statements made by a range of social historians, popular polemical writers, and literary critics writing during the last 50 years. For example, Gordon McLauchlan comments that 'a strong strain of puritanism runs through the New Zealand character' (1987: 51), Bill Pearson asserts that 'we are the most puritan country in the world' (209), and Lawrence Jones writes that 'Puritanism has been a consistent concern of New Zealand writers' (455).

Flowing from this general claim are three specific contentions. Firstly, I argue that Puritanism is a complex phenomenon, consisting of antithetical elements. It is an historical force which has enduring influence. It is a body of theological principles, but also a secular code of conduct. It is, in both its theological and secular forms, conservative and authoritarian, yet radical and liberating. Secondly, I assert that the Puritan legacy in New Zealand reflects this complexity. Puritanism was imported to New Zealand in both its theological and its secular forms. The radical/conservative dichotomy is also marked in the New Zealand environment. Finally, I claim that in the literary sphere Puritanism has been a constant influence since the publication of Mrs J. E. Aylmer's Distant Homes; or The Graham Family in New Zealand in 1862 and has inspired both pro-Puritan eulogies and anti-Puritan reactions.

These specific contentions do not meet with the same degree of critical support as the general claim about the Puritan influence. When historians and critics such as McLauchlan and Pearson speak of Puritanism, they do not refer to the theological creed and social vision of the English Puritans or the Pilgrim Fathers, but only to a debased, secularised, conservative form of Puritanism. McLauchlan describes Puritanism as 'anguished self-flagellation' (1976: 17), Pearson defines it as 'a contempt for love, a sour spit, a denial of life itself' (225), and James K. Baxter regards it as an 'austere anti-aesthetic angel' (22). If social historians and literary critics define Puritanism in a 
simplistic way, concentrating on the secular, negative elements, they also restrict its literary relevance. Puritanism is regarded as a force which authors react against. Robert Chapman highlights the prevailing critical perception when he comments that 'the attitude which the New Zealand writer takes to his society...[is] based on...an attack on the distortion produced by an irrelevant puritanism of misplaced demands and guilts' (98). Critics writing about this anti-Puritan New Zealand literary tradition herald Frank Sargeson as the central anti-Puritan figure and focus primarily on post-1940 New Zealand authors.

My thesis takes issue with the suggestion that Puritanism is solely a damaging social force and the claim that New Zealand literary responses to Puritanism are wholly negative. It also challenges the assertion that 'it was the writers of Sargeson's generation who especially focused' on anti-Puritan themes (Jones 455). In the Introduction I give an overview of the complexities and contradictions of the Puritan legacy. The discussion of the texts is divided into three parts. Section One demonstrates that between 1860 and 1940 Puritanism was regarded in a predominantly positive light by a section of the New Zealand literary community. Louisa Baker and Edith Searle Grossmann, the two authors considered in Section Two, also praise aspects of the Puritan inheritance, but criticise the way in which it fosters emotional repression and female oppression. The hint of disparagement in Baker's and Grossmann's work becomes a full-blown critique in the novels of the authors examined in Section Three.

Part One of this bibliography concentrated on the pre-1940 pro-Puritan novelists. Part Two focuses on the pre-1940 novelists who react against the Puritan heritage. While the Puritan authors hold up Puritanism as the preeminent model of moral rectitude, sexual purity, individual and social responsibility, committed endeavour and godliness, the anti-Puritan authors see Puritanism as a restricting force which represses individuality and passion, fosters social conformity, encourages materialism, distorts natural human impulses and traps believers into out-dated and damaging modes of thought and conduct. For some authors theological Puritanism is the main focus of attack, but most critique the secular Puritan legacy. The anti-Puritan attitudes of these authors are a product of belief and background. For authors such as Adams and Bolitho, who experienced the harshness and repression of a Puritan upbringing, rebellion is a dominant theme in both their own lives and their fiction. The anti-Puritan attitudes of other authors are the result of a commitment to rival belief systems. Satchell, Chamier and Morton were all religious sceptics influenced by Darwin's evolutionary theories, while Wardon's and Devanny's socialist convictions fostered their antipathy to Puritanism. Adverse experiences of Puritan morality and values inspired the 
protests of the remaining authors. Grossmann, Clyde, Mander and Hyde reacted against the patriarchal side of Puritanism. Lee's and Mulgan's antiPuritan sentiments were fed by the ostracism visited on those who contravene the middle-class moral code. Regardless of motivation, the anti-Puritan authors are linked by their crusading zeal, their desire to purge society of the taint of Puritanism.

Each entry in the bibliography consists of two parts. First I provide a brief biographical sketch and then I discuss the novel(s) of that author, highlighting the key anti-Puritan aspects of each text. Some of the authors considered, particularly John Mulgan, Jane Mander and Robin Hyde, are well known with some of their fiction still in print. As with Part One of the bibliography, I also focus on the forgotten novelists of the New Zealand canon. These novelists, as with the Puritan novelists considered in Part One of the bibliography, have limited artistic vision and technical. However, as social documents providing an insight into the reaction against the Puritan influence in pre-1940 New Zealand these novels are invaluable.

\section{ANNOTATED BIBLIOGRAPHY: REACTIONS AGAINST PURITANISM}

Adams, Arthur $\mathrm{H}$.

Adams was born in Lawrence in 1872. Educated at Otago Boys' High School, he then went to Otago University where he had a scholarship. Once he had graduated as a BA, he started studying law, but found it uncongenial and gladly relinquished it for an opening as a junior reporter on a Wellington newspaper. Adams worked as a journalist in New Zealand, Australia, China and England. He settled in Australia and was literary editor of the Sydney Bulletin. Adams published several novels and a volume of short stories, The New Chum and Other Stories (1909), under his own name and four pornographic novels under the pseudonym James Jones. Nelson Wattie describes the latter as 'titillations of partial nudity' (Wattie 2). Adams also wrote three plays and provided the libretto for Alfred Hill's cantata Hinemoa (1896) and opera Tapu (1903). He was a well-known poet, publishing Maoriland and Other Verses (1899), The Nazarene: A Study of a Man (1902) and Collected Verses (1913). Adams died in 1936. This bibliography focuses solely on Adams' anti-Puritan, serious fiction.

Galahad Jones (London: John Lane, 1915) 
Set in Sydney, Galahad Jones is a critique of middle class respectability and a call for the prosaic to be leavened by a dash of romance. Galahad and his wife Em have lost the sparkle with which they started life and have settled into a repetitive, soul-destroying routine of work and suburban life. Respectability is Em's God. Her biggest preoccupation is with keeping her linoleum polished and door-stone white. Cleanliness gives her 'a feeling of rigid and satisfying respectability' (78). In this battle to keep up appearances love is lost. Galahad's position is both more hopeful and more tragic, for he realises that his life is empty. He longs for '[r]omance and adventure, wonder and illusion' (12). His encounter with Sybil Beach, a damsel in distress, frees his soul from 'the sordid shackles of the prosaic' (29). The resurgence of romance within him opens his eyes to the way life has calloused his relationship with Em. The actions that spring from this realisation - a morning kiss, a compliment, an extra chore done to spare Em - bring a fresh injection of love into the marriage. Galahad and Em will never be figures of chivalric romance - that is not Adams' point. They remain sober, middle-aged, restrained, middle-class, but the shackles of respectability are broken. The closing scene of the two of them surfing on Manley Beach is symbolic of the spontaneity that has illuminated their lives.

A Man's Life (London: Everleigh, Nash and Grayson, 1929)

The autobiographical novel A Man's Life gives an insight into Adams' personal experience of, and rebellion against, Puritanism. Adams uses the flashbacks of a dying man to highlight the key moments in his hero's life. Central to the hero's childhood development is his Puritanical father. Work and church dominate the father's life. In typical Calvinist fashion, 'white was to him purest white, and black was just black. There was no give and take in any of his dealings' (175). His garden plot is symbolic of his inflexibility, his obsession with order and utility, and his repression of unwanted emotions. It is 'horribly rectangular...laid out in squares and runs'. Weeds are viciously pulled out and the plants (all vegetables) grow in 'tortured symmetry' (9-10). The father is viewed by his children as 'the stern providence that ruled their lives' and they leave home as quickly as possible (196). The hero's departure from his home is mirrored by a rejection of his father's religion. He blasphemes God to prove that God does not exist and consecrates himself to a new faith - art: 'In a moment of glorious Godlike comprehension...[he] knew himself for the anointed and consecrated disciple of poetry' (135). Departure for Australia brings mental freedom and sexual adventures, but lasting contentment only comes with his marriage. As he matures the hero's ardent agnosticism mellows to a humanist acceptance of difference. He confronts death with 
serenity, certain that 'he had had enough of life; he had lived to the utmost...When he died he passionately wanted to be dead - quite dead' (48).

A Touch of Fantasy: A Romance For Those Who Are Lucky Enough to Wear Glasses (London: John Lane, 1912)

A Touch of Fantasy is set in Sydney and warns of the dangers of illusion. Hugh Robjohn acquires magic glasses that soften the world for him. Through them, Nancy is perfect, his ideal. When he no longer wears the glasses he sees her as she really is, a fallible woman who has born a child that is not his, and he repudiates her. Adams uses this set of events to highlight the necessity of accepting reality with all its flaws and compromises. He argues that the Puritan ideal of sexual purity is unrealistic and prone to result in unwarrented condemnation of those who stray, particularly women. From a limited, Puritan perspective Nancy is an immoral slut. Hugh at first sees her in this light, a 'soiled thing' unworthy of his love and undeserving of his forgiveness (294). However, he eventually sees beyond this to an acknowledgement of the 'cruelty' and emptiness of his impossible 'dream of a woman divine' (296). He is content to take her and love her 'haloless', faulty as he himself is faulty, and rejoices that their union is no passionless ideal, but 'a thing of the flesh and the soul, common, lowly, yet in a strange new way... divine' (301). Through his 'prosaic new glasses' Hugh 'recognise[s] at last that Love is nothing but the infinite capacity of giving and forgiving' (3034).

Tussock Land: A Romance of New Zealand and the Commonwealth (London: Unwin, 1904)

Tussock Land is a bildungsroman centering on the artistic quest of King Southern. He gives up everything, even his love for Aroha Grey, in order to leave southern New Zealand and travel to Australia. This departure does not result in a realisation of his ambition. King continues to paint and dream, but is also forced to work as a lawyer for a living. The ending of the novel is particularly anti-Puritan in its discussion of sexual issues. King returns to New Zealand, hoping to win Aroha. She fears that 'she had put [King] for ever beyond her reach' by the confession of her relationship with Will (309). However, King is big enough to accept her for who she is. He does not blame her for relinquishing the chastity he himself has not kept, but offers 'a sane and steady friendship, a steady and sober love' (304). He has 'learnt to be tolerant, to make allowances, to forgive' (304). Aroha's and King's mature love, based on mutual forgiveness, honesty and acceptance of each other as flawed human beings, is Adams' ideal. His emphasis on compromise rather than perfection challenges Puritan piety. 


\section{Bolitho, Hector}

Bolitho was born near the turn of the century and lived his formative years in Opotiki and Auckland. His parents were devout Methodists and in his mother this religious fervour was combined with a devotion to respectability. In his autobiography My Restless Years (1962) Bolitho says of his mother: '[Her] ideas of behaviour were as fixed as a pattern on a plate: her motto beneath the design was 'what will the neighbours say?' (36). Bolitho's autobiography also provides a record of his rebellion against his parent's theology and his mother's doctrine of respectability. From an early age reading poetry, visiting art galleries and thinking of his English ancestors provided 'windows through which [he]... searched, for the way of escape' (53). At the age of 16 Bolitho finally 'rebelled against the piety forced upon [him]' (48). While the initial rebellion was relatively painless, although Bolitho did have to endure unceasing complaints about 'what will Aunt Nellie say?', it took him longer to escape from the legacy of guilt his upbringing placed upon him (48). After sampling Anglicanism, Theosophism and Quakerism, Bolitho finally found relief in Catholicism. He sought new horizons in first Australia (where he was the first editor of The Shakespeare Quarterly) and then Europe. He settled in England and made a career as a royal biographer and apologist. Biographies such as Prince Consort - Albert (1929) and King Edward VIII: His Life and Reign (1938) were financial and popular successes. Bolitho wrote over 60 books, including: The New Zealanders (1930), The Emigrants: Early Travels in the Antipodes (1939, written with Alan Mulgan) and two semi-political and religious parables, Empty Clothes (1934) and The Flame on Ethirdova (1930). This bibliography focuses solely on his two New Zealand anti-Puritan novels. Bolitho never returned to live in New Zealand and died in England in 1974.

Judith Silver (London: Knopf, 1929)

Judith Silver, a partly autobiographical novel, is uneven and at times marred by melodrama. However, Bolitho's depiction of the destructively repressed James Grantham demonstrates an understanding of the inner demons fostered by Puritanism. James' Puritanism is a secular Puritanism that manifests itself in his repression of emotion. Unable to freely express his love for his son Simon, James becomes obsessive. He is paranoid about every expression of individuality on Simon's part. Simon's first act of rebellion, running away after he has been whipped, ignites James' jealous, repressed love to violence. Gazing at his sleeping son he 'looked at his thumbs. If he lowered them on to that lovely throat, it would be finished. Simon would never 
grow up, away from him, into the world' (28). James' battle with his murderous impulses and his obsession with his thumbs is treated with sympathy and restraint. Less effective is the final melodramatic eruption of violence. Jealous of Simon's love for Judith, James sleeps with his maid Muriel. Her pregnancy tips his guilt over the edge into madness and he murders her and kills himself. Love which cannot find expression becomes a 'selfish, destroying love' capable only of violence, self-torture and ultimately 'self-destruction' (237). Bolitho's anti-Puritanism is evident not only in his depiction of the destruction wrought on the psyche by Puritan inhibitions, but also in his celebration of Simon Grantham's pagan spirit. Simon is untouched by his father's Puritan hang-ups, reveling in running naked on a New Zealand beach and living a balanced life of study and pleasure when he studies at Cambridge. The only Puritan remnant in Simon is a priggish intolerance of sex, seen in his discomfort with his father's relationship with Muriel. He is saved through his love for the Catholic Judith Silver. Through her influence Simon comes to an understanding of his father and adopts her ethic of Catholic love rather than Puritan intolerance. The novel is unique among New Zealand novels of its time for the way it offers liberation from Puritanism through religious faith.

Solemn Boy (London: Chatto and Windus, 1927)

The autobiographical Solemn Boy charts Timothy Shrove's journey away from Puritanism. This is embodied in his Methodist family, particularly his mother. Mrs Shrove constantly exhorts her son to 'live as good a life as his father and adhere to the Christian faith' (140). Living a good life involves conforming to the rules of society. For Mrs Shrove, 'originality, individuality, and personality were things to be avoided' (32). From an early age Timothy is conscious that these are precisely the attributes that attract him. He is aware that he has 'a second self inside him, a second self that made journeys along the sunny lanes of Imagination and down the cool quiet valleys of Thought. In these places...the Individual Timothy stepped beyond the boundaries born in the Shrove household' (23-4). While he keeps this second self hidden from his parents, it is fostered by his out-spoken Grandmother Spencer and his friend John Fielding. By the time John dies in the war Timothy has jettisoned his Puritan heritage. He devotes himself to a literary career and moves to Australia. Travel and art, the twin mediums of liberation in so much of New Zealand anti-Puritan literature, are Timothy's salvation from Puritan mediocrity. This first half of the book has the ring of emotional intensity and the force of conviction. Unfortunately, the second half fails to maintain either the narrative interest or fresh writing of Bolitho's childhood recollections. The mature Timothy becomes tedious and slightly pompous and the culmination of his tortuous relationship with Grace Merton brings only relief. It is perhaps no 
coincidence that the intensity fades after the death of John. The novel gives the impression that, consciously or unconsciously, Bolitho wanted to write a record of a homosexual relationship - and could not. Bolitho is at his best writing about rebellion, once that is accomplished his novel becomes contrived and pedestrian.

\section{Chamier, George}

Chamier was born in 1842 in England. He was part of a vibrant French Huguenot family with a strong religious, philosophical and artistic heritage. While Chamier jettisoned the religious elements of his family past, he continued the tradition of philosophical and literary endeavour. After receiving a scientific education in Dresden, he immigrated to New Zealand in 1860 . He worked as a cadet on a North Canterbury station and then as a road engineer and surveyor, experiences which form the base of his two novels. Moving to Australia in 1869, he continued to work as a engineer and in the 1880 s published a pamphlet on The Utilisation of Water in South Australia. He also wrote a volume of essays entitled War and Pessimism (1911). These essays articulate Chamier's mature philosophy of 'a stoic acceptance of pessimism' (Joan Stevens: 1970 xi). He defines the pessimist as one who 'expects but little from human nature and is therefore rarely disappointed... he pursues his even way, keeping rather in the shade, endeavouring to do what is right, and content to fulfill all manifold duties' (Joan Stevens: 1970 xi-xii). Chamier died in Australia in 1915.

Philosopher Dick: Adventures and Contemplations of a New Zealand Shepherd (London: Unwin, 1891)

Philosopher Dick focuses on the fortunes of a recent immigrant to New Zealand, Richard Raleigh. He is the philosopher of the title, acquiring this name because of his relaxed, intellectualised attitude to life. He is a sceptic and a fatalist who has rebelled against his Puritan upbringing. His mature philosophy is that while faith and credulity may be attractive, they are no longer realistic possibilites in the age of science: 'Nothing remains which the crucible of modern science cannot disintegrate, or that the critical spirit fails to expose.' (76). When Richard arrives in North Canterbury his remaining Puritan illusions are exploded, particularly his belief in the work ethic. He comes to New Zealand convinced that 'a new country, wide and beautiful' offers opportunities of 'life and progress' (228). However, he soon discovers that this dream is delusive. Many, such as his friend Stead, struggle continuously but achieve nothing and Richard concludes that excess of 
energy is bad and that zeal is disastrous' (369). He is content to live as a shepherd with time to philosophise and read.

A South-Sea Siren, ed. and intro. by Joan Stevens, 1895 (Auckland: Auckland University Press, 1970)

A South-Sea Siren is the sequel to Philosopher Dick. Richard Raleigh has now moved to the small Canterbury town of Sunnydowns where he works as a surveyor. Chamier reinforces his anti-work ethic message in this novel. Richard works when he has to, but is 'indolent on principle', spending much of the day 'in a reclining attitude, smoking the pipe of peace, and profoundly indifferent to time and occupation' (112). Chamier also attacks the insularity and pettiness of small town settler society. Sunnydowns is dominated by a belief in 'the paramount necessity for "getting on", of outdoing others. This is illustrated in the Episcopalian determination to best the Methodists, who build a chapel 'TO THE GLORY OF GOD'. The Episcopalian response is to erect a church 'TO THE GREATER GLORY OF GOD' (101). While A South-Sea Siren is strongly anti-Puritan in its attitude to the work ethic, there is a residue of Puritan morality in the novel. The Siren of the title is a snake-like temptress. Richard is shown to be foolish and misguided for succumbing to a 'wanton' and 'designing woman' (233). As the novel progresses Richard moves away from the Siren towards the stability and moral purity of the Puritan Alice. Chamier by no means exhorts Richard to be like Alice. Richard's scepticism, his consciousness of the uncertainty of life, his ability to strip away social pretences are all central to Chamier's outlook. However, there is a strain of indolence, a lack of direction and weakness in Richard that Alice's Puritan rigour is able to balance and at times correct.

\section{Clyde, Constance}

Clyde was born in Scotland in 1872. In an autobiographical fragment, she describes herself as a 'member of a large family who came out to New Zealand (Dunedin) when the writer was between seven and eight years of age; was educated at the Girls' High School, Dunedin, began writing verses for the Witness (Otago). First story published (that was paid for) appeared in the Dunedin Star. Came to Sydney September 1898, have since worked for all the best Australian papers, but also for one or two English papers.' (Australasian Autobiography ATL MS 0095) Much of her journalistic career was spent writing for the Sydney Bulletin and her articles speak of her interest in social, feminist and literary questions. Clyde was particularly concerned about the future of women's writing. In 'The Literary Woman' she praises the 
way in which contemporary female writers had moved beyond 'expressing...what men expected them to think' about relationships and urges them to continue to 'make brilliant discoveries in the realm of the emotions' (ATL MS 13/19/1 23 Sept. 1987, 4). Clyde's only novel, A Pagan's Love, puts these principles into practice, focusing on the traumatic emotional journey of the heroine. Some reviewers attacked the novel as 'unpleasant' and 'nasty', but 'C. J.' in the Bulletin praised the way in which 'the book...records the moulding of a woman character by the narrow Otagonian environment, and how that character was hammered flat and remoulded on broader lines by contact with the hero of the book in Sydney' (ATL MS 13/19/1 23, Sept. 1987, 6).

A Pagan's Love (London: Unwin, 1905)

In A Pagan's Love Clyde is explicitly contemptuous of Puritanism, which she dismisses as 'this coarse, church-belled heathenism' (217). She sees it as a narrow, barren, blinkered creed suitable for the respectable conformists who live in the Presbyterian Otago community of Waihoa. The attractive alternative offering deliverance from this stultifying religion is paganism. For Clyde, this is a blend of atheism, sexual equality and a new morality. The novel charts the progression of the heroine, Dorothea Wylding, away from Puritanism towards paganism. Growing up in Waihoa, Dorothea is imbued with a strict sense of morality and a belief in respectability. This begins to be undermined when she travels to Sydney, the 'laughing pagan city' (85). Here she meets the feminist Ascot Wingfield, an independent career woman and solo mother, who teaches Dorothea of the need for women to have both an intellectual and an emotional life. Dorothea is also reunited with childhood friend Edward Rallingshaw, the pagan of the title. A married man, he tries to persuade Dorothea to live with him in a free love union. Just as he wears the last of her resistance down he dies in a fire. While this at first appears to reinforce the Puritan theological code of transgression and punishment, it eventually results in the defeat of orthodoxy. Returning to Waihoa, Dorothea marries the Rev John Archieson. When she leaves him to return to Sydney he in turn discovers that the Puritan code is limiting. In a final sermon he questions whether 'there is such a thing as sin' and declares that 'it is not the higher but the broader life that we want; we need our minds enlarged rather than our souls purified' (307). John's heterodoxy reunites him with Dorothea. The ex-Puritan hero and heroine resolve to work together to free others from the religious and moral bondage they have experienced and to promote 'a new morality and religion of love rather than law, of fulfillment rather than denial' (Lawrence Jones: 130). 


\section{Devanny, Jean}

Devanny was a committed communist with a deep concern for the rights of women. In her autobiography, Point of Departure (1986), she insists that these two interests are compatible, emphasising that a fundamental part of 'communist theory' is a rejection of 'discrimination between the sexes', 'a double standard of morality' and the 'economic and sex-enslavement of women' (16). However, her own experiences of entrenched male chauvinism in the Australian Communist Party left her ambivalent towards communist practice. Her novels reflect this ambivalence. Devanny was resistant to the feminist label, but in her writing, if not in her professed beliefs, communism takes second place to feminism. Born in 1894, Devanny's childhood was spent in the small pioneering settlement of Ferntown near Golden Bay. Her father, William Crook, indulged in periodic drunken sprees that gave Devanny a life-long horror of alcohol. Likewise, her mother's submission to an unceasing round of child rearing contributed to the formation of Devanny's feminist views. From an early age Devanny read socialist books. Her socialist ideas continued to grow after her marriage to Hal Devanny when she was 17. Hal was a miner deeply involved in the Miners' Union and both he and his wife belonged to a small Marxist study group. At the same time Devanny's feminist sympathies were strengthened by interaction with other mining wives and she became an outspoken advocate of contraception. The Devannys' move to Fairfield coal-mine near Dunedin gave Devanny the opportunity to take piano and violin lessons. A talented musician, she considered a musical career but gave up music when her daughter Erin died, feeling that she had been neglectful of her children. Moves first to Wellington and then Sydney opened up new avenues of socialist activity. In Sydney the Devannys joined the Australian Communist Party. Lecture tours and propaganda absorbed much of Devanny's time, but she also cultivated her literary interests. The communist hierarchy disapproved of Devanny's literary activities, but she 'would not submit to being hampered...by the Party's sectarian narrowness' (Devanny: 206). Her independence and outspoken championship of women were factors behind her expulsion from a Party dominated by petty chauvinists. During her active communist years Devanny lived apart from her husband and had a relationship with Party Secretary J. B. Miles. Eventually reconciled with Hal, Devanny moved with him to Townsville, Queensland. She lived there until she died of leukemia in 1962. A more detailed picture of Devanny's life can be found in her autobiography and in Carole Ferrier's Jean Devanny: Romantic Revolutionary (1999). Devanny wrote novels set in both New Zealand and Australia, but this bibliography concentrates solely on the New Zealand fiction. 
Bushman Burke (London: Duckworth, 1930)

Devanny's attitude towards alcohol, promiscuity and sloth in Bushman Burke can be termed Puritan. This critique of vice is in keeping with Engel's insistence that social evils are a product of capitalism and that those who reject vice align themselves with the enlightened socialist order. The hero, Taipo Burke, is a clean-living, hard working bushman. When he inherits wealth he channels his money back into the land, continuing to work hard himself and providing employment and opportunity for other men. Taipo is dismissive of the socialites he encounters in Wellington, declaring: 'The lot of you are spoiled for want of work' (120). He is also imbued with a conventional morality. While he is attracted to Flo Wallace, he detests her heavy make-up, preference for night clubs and drinking. Such is his conventionality that he naively expects marriage to work a magical transforming influence through its 'sacred obligations' (93). When Flo shows no evidence of reformation he first attempts to change her and then leaves her when he learns of her affair with Rangi Fell. Devanny's attitude towards Taipo's Puritan moralising is more ambivalent than her straightforward approval of his drive and dedication. While denouncing Flo's promiscuity, Devanny highlights the hypocrisy and chauvinism of Taipo's position. Flo cuts through her husband's judgementalism, emphasising that he chose her because her 'type stirs [his] passions' and must live with that choice (107). While Flo gradually changes, becoming much more natural and realising that she loves Taipo and wants to be faithful to him, she refuses to 'live in the bush all her life and do menial work and have babies' (231). Taipo learns to accept Flo as an individual rather than an appendage to himself. They complement each other, Flo's independence puncturing Taipo's complacent chauvinism, while his primitive Puritanism works to strip away her degeneracy.

The Butcher Shop, ed. and intro. by Heather Roberts, 1926 (Auckland: Auckland University Press, 1981)

Banned in New Zealand when it was first published, The Butcher Shop highlights the contradictions between communism and feminism. Like Lenore Divine and Poor Swine, it is anti-Puritan in its attitude towards marriage and sex. Devanny attacks the patriarchal view that a woman is a man's property. Through the socialist teaching of Ian Longstair, Margaret Messenger realises that she is a 'slave' because she is 'economically dependent' on her husband (147). Ian heralds the socialist revolution as the emancipator of both women and workers, but in his own life the inadequacies of communism from the feminist perspective are highlighted. He is a chauvinist who views his wife as a 'servant' and makes constant demands of her (149). In this he is no more 
advanced than Barry Messenger, who sees his marriage as a commercial transaction, and Angus Glengarry, who tells Margaret that she must choose between her husband and him. The socialist explanation is not sufficient for Margaret. She blames not capitalism but patriarchy for her situation. The most anti-Puritan feature of the novel is Devanny's revolutionary claim 'that the right of woman to control over her own body was inviolable irrespective of the marriage' (Devanny: 94). Margaret sees no shame in her relationship with Glengarry, but also refuses to leave or pain Barry. She rejects the male view that she should choose one man, rather than being both wife and lover. Her refusal to be the property of any man has tragic consequences. Barry drowns when he learns of the liaison and Margaret murders Glengarry in order to 'revenge the Margarets of this world' (224).

Dawn Beloved (London: Duckworth, 1928)

Like The Butcher Shop, Dawn Beloved highlights the disparity between communism and feminism. The novel is largely autobiographical and begins by providing a scathing picture of the Puritan forces the young Dawn struggles to escape from. Mrs Haliday is sexually inhibited, hating the sexual act but submitting to it out of a sense of duty. In contrast to her 'artificial standard of womanhood', Dawn is the epitome of the new woman: 'free-living, natural...fearless and brave' (62). Devanny's anti-Puritanism is also apparent in her critique of capitalist society. Dawn and her miner husband, Valentine Devoy, become committed socialists after reading Thorold Rogers' Six Centuries of Work and Wages. Dawn traces the poverty and happiness of those around her to 'the system of capitalist production' and longs for a 'future' in which 'the froth of the social order, the idle, the frivolous... [will be] knocked from its perch' $(320,345,224)$. The novel ends with Dawn's arrival in Wellington, determined to study and then preach her Marxist message to a world in need of change. While the socialist strand in Dawn Beloved is strong, the feminist emphasis dominates. Devanny protests at a society that makes slaves of its women. In part, this philosophy of ownership can be blamed on capitalist society. The poverty Dawn struggles against, the lack of freedom she experiences, the mental aridity she endures are the product of her 'environment, her position as a working class woman (223). Yet, while communist theory claims to offer emancipation for women it seems incapable of delivering in practice. Socialist males, such as Valentine, remain deeply chauvinist. Dawn refuses to be treated as his chattel and demands the right to stimulate her mind through study and accept economic help from Gavin Fuller. Looking at Val's books Dawn reflects: "Val says that socialism is the only way out. I wonder!' (225). In spite of her communist theories Devanny also wonders whether socialism is enough. Dawn's history demonstrates that 
a new feminist creed is necessary to free women from the bonds of chauvinism and Puritan convention.

Devil Made Saint (London: Duckworth, 1930)

Devil Made Saint is marred by lush overwriting and melodrama, but it makes some pertinent comments about the way in which suppressed emotions pervert and distort. The novel charts the repressed Jan Safron's rebirth as a woman of feeling. At the beginning of the novel she is egotistical, possessive, emotionally repressed and potentially violent. Jealous of her husband Francis and daughter Adelaide's mutual love of music and each other, she retreats into an ugly inner world. Her repressed emotions fester and ultimately emerge as hatred and violence. She grabs the wheel of the car her husband is driving, intending to kill them both and succeeding in killing him. His death breaks the 'hard husk' of Jan's ego and through suffering she is born to a 'new life' (71, 54). Love, tenderness and generosity replace her cold bitterness. When Carl Aubrey, Adelaide's husband, makes her his 'muse' the last barrier is removed between Jan and her 'natural development' (118, 122). Her emotions find expression in her overwhelming love for Carl, an emotional fulfilment that eventually leads to sexual fulfilment. Her rebirth is complete, the Puritan 'devil' has been 'made saint'. However, Jan does not enjoy her new, emotionally rich life for long. She is 'sucked dry' by Carl and dies on a wave of ecstatic love (257). The novel thus ends with a protest against male selfishness and egotism.

Lenore Divine (London: Duckworth, 1926)

Set in Wellington, Lenore Divine is the novel in which Devanny's communist and feminist philosophies are most closely integrated. Her heroine is one of her fictional selves and is both a committed socialist and an ardent feminist. Lenore Divine works as a journalist, has ambitions to be a novelist and takes pride in her economic independence. She is also free thinking and unconventional and holds extremely anti-Puritan views regarding marriage and sex. Lenore refuses to marry her lover Holly and dismisses his complaints as misguided convention: 'You attach too much importance to formal ceremonies, to conventionality. You think you are not my husband because we have not had a few official words said over us. I believe that true marriage consists in the union of a man and a woman between whom there is mutual love...' (45). Lenore's anti-Puritan feminism is the product of her socialist philosophy. She views marriage as a capitalist institution which tries to 'shackle' and 'bind' women 'with the chains of economic independence' and 'make of her a gilded ornament' (149). Lenore preserves her legal freedom by remaining single and her economic freedom by continuing to work even when 
she is in a relationship. While her ideal is a monogamous union with a man she loves, an ideal she eventually finds with Kowhatu, she reserves the right to transfer her affections and to maintain control over her body and her resources.

Poor Swine (London: Duckworth, 1932)

Poor Swine is one of the most radical of Devanny's New Zealand texts. It provides a very different angle on promiscuity to Bushman Burke. The promiscuous woman is the heroine of Poor Swine and Devanny discusses her situation with compassion and understanding. Lilian Sweet has had a string of sexual relationships since she was little more than a child. An early pregnancy leads to marriage with the father, Laurie Cameron, but this does not prevent her from embarking on affairs with Dr Eddie Stallard and Aspro Jimmy Logan. The Puritan mining communities of Granity and Deniston look with disfavour on Lilian, seeing her as a 'disgrace' (36). However, Devanny's view of her heroine is very different. She makes frequent references to Lilian's 'innocence', 'freshness' and 'inward beauties of soul' and likens her to a lily $(95,257)$. Lilian is praised for being instinctive, uninhibited and natural. Those who 'arraign' Lily before the conventional bar of 'right and wrong' are seen by Devanny as 'dam[ing]...life's stream' (155). Devanny's tenderness and understanding towards her heroine is the result of her communist thinking as well as her feminism. She stresses that Lilian's promiscuity is inevitable in a society driven by capitalist demands. Bound to a drunken wastral and completely lacking in resources, Lilian has no choice but to exploit her power over men to put food on the table and finance her singing lessons. She is freed from the cycle of 'unloving parents; children of half-brutish delight; children of accident, children of sin' through the love of Julian Greville who accepts her as an 'equal' and treats her with 'trust and respect' $(80,270,276)$.

Riven (London: Duckworth, 1929)

Riven is the most stylistically innovative of Devanny's novels, using free indirect thought and interior monologue to create a picture of Marigold Jerring's inner world and gradual transformation from repressed Puritan to adventurous free-thinker. At the beginning of the novel she is inhibited and conventional, her thinking bound by Puritan ideas of what is 'proper'. She disapproves of smoking and scanty clothing, is too embarrassed to tell her children the facts of life and reacts with horror when she hears of Fay's pregnancy. Her prudery is matched by her dutiful wifely submission. She rejects her son Hadrian's suggestion that she go with him to Europe because '[c]ustom is too tight on [her]' (90). However, within she has moments of rebellion, dreaming of 'lands where yellowed fruits hung perpetually from quiet 
trees' and herself 'transcendent' in the 'sunshine' (18). Devanny's belief that the path of convention and submission is false and damaging is demonstrated through the way in which Marigold gradually changes. Fay's pregnancy and her husband's infidelity cause her to challenge her doctrine of respectability. She becomes conscious that her life is a 'vast waste' of potential and carves out a new niche for herself as the self-appointed emancipator of fellow middleaged women (281). The novel ends with Marigold planning to realise her dreams of travel and adventure. Conscious of 'a new fulfilment', an 'expansion of personality' the once staid and inhibited Marigold calls to her friend Alicia: 'Let's be mad. Let's be gloriously mad!' (318-9).

\section{Grossmann, Edith Searle}

Grossmann's attitude to Puritanism is ambivalent. An ardent feminist, her political views and moral outlook bear the Puritan imprint. Yet she is also antagonistic to Puritan patriarchy and orthodox religion. Her novels reflect this complexity. Born in Australia in 1863, Grossmann came to New Zealand in 1879 with her parents, Mary and George Searle. She attended Invercargill Grammar School and then Christchurch Girls' High School, where she became head girl. The principal, Helen Connon (later Helen Macmillan Brown), persuaded her to go to university and in 1880 Grossmann entered Canterbury College. There were then only three girls at the college, but by the end of her course there were about 100 female students. Grossmann graduated BA in 1884 and received an MA with first-class honours in Latin and English and third-class honours in political science in 1885. After graduating she taught at Wellington Girls' High until her marriage to Joseph Grossmann in 1890. Most of their married life was spent apart. Joseph was convicted of fraud in 1898 and Grossmann lived in England and Europe for 10 years working as a free-lance journalist. Both as a journalist and as a novelist Grossmann wrote of the need for women to be educated and independent. Helen Connon was her model of a woman who was both a stimulating teacher and a wife and mother, although in her 'Life of Helen Macmillan Brown' (1905) Grossmann laments that her mentor's energy was sapped by domesticity. Grossmann's own life is also a demonstration of feminist principles in action. In her obituary, 'Edith Searle Grossmann Pioneer', Alan Mulgan wrote:

New Zealand is much indebted to Edith Searle Grossmann. She set examples of an intellectual life lived long and consistently, and of service to shining ideals. She enriched the small body of out creative literature... Generations of women graduates walk on the road that she and her contemporaries made. (4) 
Angela: A Messenger, published under maiden name Edith Howitt Searle (London: Simpson and Williams, 1890)

Grossmann's first novel, Angela: A Messenger, is a trite, moral tale, more proselytising tract than fiction. It has much in common with the salvation novels of Guy Thornton and Bannermann Kaye (considered in Part One of this bibliography). The world of the novel is a Puritan world in which goodness is inseparable from God and evil another word for Satan. Even the inately pure and virtuous, like Angela, need to be redeemed through a living relationship with Christ as Saviour. Conversion through contact with Salvation Army revivalists leads to Angela's dedication to a life of Christian mission. After service in Sydney her faith is put to the ultimate test. Attacked by a depraved drunk, Angela dies with Christ's name on her lips. The fusion between evil and drink makes a prohibition statement that connects the novel with the work of anti-alcohol novelists such as Susie Mactier and Bertha Cameron (see Part One of this bibliography). Grossmann's feminism in this early novel is narrow, but foreshadows later developments in her writing. Angela is pure and good, an upholder of virtue in a corrupt world. When Marks tries to seduce her he realises 'that he could not move her; the breath of her chastity went against him like a cold mountain wind' (67). Yet, while Angela's purity repels evil, her character is contaminated by contact with Mark's vileness. His 'hideous revelations' shame her and she is unable to forget what she has heard (67). Significantly, evil in Angela emanates from men, a gender link which hints at Grossmann's later attack on male power and female oppression.

The Heart of the Bush (London: Sands, 1911)

Grossmann's final novel, The Heart of the Bush, is a complete departure from the feminist Puritanism of the earlier Hermione novels. It is less agenda driven, an aesthetic event rather than a tract. Grossmann remains interested in the dynamics of marriage relationships, but Adelaide's and Dennis' marriage is a portrait of a real, human relationship that does succeed. The novel emphasises the need for understanding, communication and compromise in a relationship. Adelaide has to realise that Dennis devotes so much of his energy to his work because he wants to provide for her, while he must come to accept that his presence is more important to her than the material refinements he seeks to provide. The relationship is convincingly sensual and this celebration of sexuality is the most radical departure from Grossmann's previous novels. She writes of the passion Dennis feels when he looks at and touches Adelaide: 'He was always finding some new charm, and now his eye fell on a slight incurve, not quite a dimple, of the blush rose 
flesh, where the rose tint ever so slightly deepened just at the sitting of the round young neck and soft shoulder, and he kissed it once or twice' (239). Adelaide is similarly stirred by Dennis' physique. She watches him fishing and thinks 'with heightened colour that he was a grand type of man, and she compared him to the statue of Poseidon' (170). The novel also offers a critique of the Puritan work ethic. Grossmann stresses that dedication to labour can destroy a relationship. Happiness is restored to the marriage when Dennis sells his shares and resigns his seat on the boards of the Farmers' Refrigerating Meat Co and the Wainoni Flat Creamery, placing family before work. Adelaide and Dennis enjoy a pastoral idyll; a life of picnics, poetry and sex.

Hermione: A Knight of the Holy Ghost (London: Watts, 1908)

Hermione: A Knight of the Holy Ghost is the sequel to In Revolt. It is much more consiously feminist and therefore more theoretical. In the Preface Grossmann makes it clear that she sees the novel as her contribution to the women's movement, the 'great struggle which aims at overthrowing the power of a small privileged class over a large dependent class, and the power of one privileged sex over a more dependent sex.' The novel provides a comprehensive analysis of both the moral and the social aims of early feminism. Grossmann's rejection of orthodox religion is confirmed in Hermione. She writes that: 'When [Hermione] had revolted against sex tyranny, she had cast off religious faith with it' (47). Hermione embraces a new humanist faith in the 'Divine Spirit' within each individual, which prompts men and women to live a 'higher life' (296-7). Women have a special role in bringing this 'higher life' to fruition. Grossmann writes that 'the aim of the noblest Woman's Rightists was to create a purer social system...women like Hermione...were animated by a passionate desire for a loftier ideal of love and home and of the destiny of the race' (175). In particular, Grossmann preaches about the need to 'raise the idea of marriage' (181). Her ideal is a relationship of 'pure love', a chaste, spiritual love (182). Such is Hermione's repugnance for sex that she speaks of it as a 'monstrous, unregulated, unnatural passion' (261). Her experiences with Bradley have made her feel that she is '[c]oveted, suspected, outraged, possessed - as if [her] body were not the free instrument of [her] mind' (363). In conjunction with this Puritan-like protest against sexual depravity, the novel advocates the need for legal and social reform. Hermione devotes her life to improving the position of women, establishing a commune in Melbourne to provide refuge for abused women and 'equal education' (202). The novel also attacks divorce and property legislation. When Bradley finds Hermione the law refuses to grant her request for divorce and grants him control over her property. Hermione is left with 
nothing except her determination never again to put herself in Bradley's power. In a world that offers her absolutely no protection, suicide is Hermione's only means of escape.

In Revolt (London: Eden, Remington, 1893)

Set in Australia, In Revolt makes its feminist protest through the tragic history of Hermione Howard. Eager to go to university and shape her own life, Hermione is forced into marriage with Bradley Carlisle by her aunt. Grossmann protests against male authoritarianism and drunken brutality through her depiction of Bradley. From the first he is determined to 'quell' Hermione, 'to be [her] master' $(64,181)$. When Hermione disobeys him, he uses his superior physical strength to extract obedience from her and punish her. His brutality is heightened by alcohol and in one drunken rage he murders his son Ernest. By extension the novel not only critiques an individual sadist, but also the system which upholds his authority. Hermione bitterly reflects that 'this was what had mocked her - that he had the right to torture her to his brutal will, the right confirmed by law, sanctified by Scripture, and applauded by society' (387). Thus far the novel reads as a conventional feminist Puritan attack on masculine abuse of power (see the fiction of Ellen Ellis and Elsie Story considered in Part One of this bibliography). However, while the main thrust of In Revolt is a protest against the physical, legal and economic power men exert over women, ultimately it is not Hermione's legal powerlessness which ties her to her husband, but her belief that submission is a noble virtue. Grossmann critiques Christian teaching, particularly Paul's injunctions to women to be obedient, emphasising that traditional Christianity is one of the devices society uses to reinforce male authority and enforce female submission. Hermione's journey to independence involves a rejection of these religious beliefs. When Bradley kills Ernest she realises that the great sin was her marriage' not her desire for liberty and leaves him (416).

\section{Hyde, Robin}

Hyde was born Iris Wilkinson in Capetown, South Africa in 1906. She spent her formative years in Wellington, her childhood marked by fierce arguments between her socialist, agnostic father and her religious, Empire-loving mother. From an early age Hyde delighted in words and when she left Wellington Girls' College she began work as a reporter. Three events in her late teens affected her deeply: the departure of Harry Sweetman for England without her and his death shortly after arrival, a knee infection that left her permanently lame, and her pregnancy after an affair. Refusing to marry the father, Hyde 
went to Sydney. She named her stillborn son Robin Hyde and thereafter used that name as her pseudonym. The birth of her son Derek in 1930 further alienated a family already disapproving of her unconventional conduct and led to Hyde's sacking from the Wanganui Chronicle. Poor, unemployed and isolated, Hyde was admitted to Auckland Mental Hospital as a voluntary patient after a suicide attempt in 1933. Here she enjoyed a period of creativity publishing poetry, fiction and a collection of prose writing. This productive literary period was characterised by a growing awareness on Hyde's part that she was a New Zealander and she increasingly uses both the New Zealand landscape and New Zealand people in her fiction and poetry. Yet the world beyond New Zealand beckoned. Hyde reached England after time in China and Hong Kong. III, poor and discouraged by the lack of interest in her work, Hyde took her own life in 1939. Throughout her life Hyde was conscious of a sense of alienation and isolation. This resulted in an unsuccessful lifelong search for what Hyde terms 'a home in this world' (1934: 10). This is not a home in the conventional sense with 'four walls and a roof on top', but a state of mind, 'a sort of natural order and containment, a centre of equipoise' (10). This feeling of isolation is coupled with a discontentment with contemporary New Zealand society. Hyde writes of her 'passionate desire to make the world over again...And isn't this a good desire? Is society really so sweet smelling that we can see no noticeable dung hills?' (Body: 57). She believed that artists needed to be reformers, not only critiquing but also seeking to transform the world they write about. This bibliography focuses on the four novels that provide a critique of contemporary society. Hyde also published a historical novel, Check to the King (1936), a commentary on life and literature, Journalese (1934), a record of her travels in China, Dragon Rampant (1939), and several volumes of poetry.

The Godwits Fly, ed. and intro. by Gloria Rawlinson, 1938 (Auckland: Auckland University Press, 1980)

The autobiographical The Godwits Fly provides a comprehensive critique of Puritanism and analyses contrasting means of escaping from provincial Puritan New Zealand society. Augusta Hannay and her daughter Carly embody all that can be stultifying about the Puritan code. They stand for family, duty, respectability, advancement and convention. Augusta has moments of revelation that '[d]rudging in little houses, bringing up children, heckling John to make him what he wasn't, and didn't want to be - that wasn't life' (176). She dreams of a white house in England, surrounded by Spring flowers, but remains trapped within her domestic cycle of life: 'Man, woman and child; man, woman and child' (119). Carly is even more completely Puritan, wanting to stay within the known, safe confines of obedience to her 
mother and the rules of respectable society. The narrowness and inadequacy of provincial Puritanism is highlighted by the way the central characters attempt to rebel against conformity. John Hannay seeks escape through forging a new identity as a working man. He adopts the outside signs of socialism, such as rough speech and corns on his feet, but remains trapped within his family duties and obligations. Socialism in The Godwits Fly brings enlightenment, but not freedom. Likewise, the godwit dream of a better life in England proves elusive. Timothy Cardew wastes the artistic potential of his young adulthood with thoughts of what he will be and do when he reaches England. However, his 'great adventure' brings not a realisation of potential but death (179). Only Eliza Hannay succeeds in moving beyond Puritanism to a sustainable alternative. Significantly her new creative ethic is found within, through a discovery of her 'own undiscovered sel[f]' and her skill as a poet (136). The inner world of creativity and individuality is seen by Hyde as the only true liberation from the confines and constraints of the Puritanism that dominates society.

Nor the Years Condemn, ed. and intro. by Phillida Bunkle, Linda Hardy and Jacqueline Matthews, 1938 (Auckland: New Women's Press, 1986)

Nor the Years Condemn is the sequel to Passport to Hell. It traces Starkie's increasingly hopeless search for community in Depression New Zealand. He tells Terry Moore: 'There's nothing l'd like better than a place of my own, and a girl like you to work for...' (79). This tentative attempt to secure a home comes to nothing, Starkie is not respectable enough for Terry's parents and she leaves him. Likewise his cousin Patrick's wife Elsie freezes him out of her middle-class Australian home with her snobbish disapproval. Starkie always seems to be 'on the other side of the fence' (74). When the forces of Puritan respectability do not deny him a place within the fence, poverty destroys his brief moments of respite. After his wife Ritehei's death Starkie struggles to keep the family together. The threat of hunger, eviction and separation eventually forces him to contemplate suicide. Hope is restored by the fruit lady. At last Starkie appears to have established a permanent tie of feeling, a home full of 'warm things' (352). However, in order to do so he has to relinquish some of his lawlessness and independence. Hyde suggests that society exacts a price for providing community. Starkie's personal journey takes place against a wider historical canvas. Through Bede Collins and Macnamara, Hyde emphasises that the prevailing materialistic, capitalist philosophy needs to be swept aside by the cleansing, invigorating effects of socialism. 
Passport to Hell, ed. and into. by D. I. B. Smith, 1936 (Auckland: Auckland University Press, 1986)

Passport to Hell is a fictionalised biography of Douglas Stark. Hyde found his history compelling, 'a queer true terrible story - this story of a living man...that simmered until written' (letter to J. H. E. Schroder 1936, ATL MS 0280). Starkie is the archetypal man alone figure, alienated from society by his ethnic difference and his instinctive refusal to be caged. Part of Starkie rejoices in his difference and cultivates his anarchic qualities. Another part of him desperately seeks to end his isolation by forming communal bonds, particularly with mates in the army. Both Starkie's anarchic individualism and his need to belong highlight the defects of Puritan society. His rebellious independence is an attractive alternative to Puritan conformity, a conformity that is largely responsible for his alienation, dismissing him as 'a savage' because of his Red Indian and Spanish racial mix and his failure to be behave 'respectably' (37). The novel ends with Starkie being questioned on his charge when he returns to hospital after a spree in Wellington. He replies: Charged with being Starkie, sir; and God knows what else' (214). Hyde attacks a society that turns individuality and difference into a crime.

Wednesday's Children, ed. and intro. by Susan Ash, 1937 (Auckland: New Women's Press, 1989)

Wednesday's Children focuses on the title character's imaginative rebellion against the forces of bourgeois Puritanism. These forces are given concrete form in the Rev. Crispin Westmacott and Brenda Gilfillan. Crispin's 'thin lips' and 'tallow colour' are symbolic of his mean-spirited religion (33). To him Wednesday is a 'harlot' and an 'evil doer' who indulges in 'degraded practices' $(33,42,35)$. Likewise, Brenda lives by a creed of 'marriage and duty and home and... position' and can see only shame in Wednesday's activities (237). For years Wednesday lives in this environment as a household drudge. Reaching breaking point in this living death, Wednesday concluded that death is the only solution. The win of lottery money gives her the courage to keep on living, but in her own way. She breaks free from the stifling Puritan respectability of the Gilfillan home and creates her own alternate reality. As the fortune-teller Madame Mystera she brings fun and enjoyment into the lives of other women trapped in a cycle of poverty and domestic drudgery. Even more importantly, Wednesday creates a fantasy life for herself on an island in Auckland harbour. She peoples this island with imaginary lovers and children, announcing each 'birth' in the newspaper to shock her family. In the Gilfillan household Wednesday had been a brown, silent, submissive shadow. Rebellion gives her 'independence', a consciousness of her own creative powers and a belief that she is 'so tough that nobody could break [her]' (113). 
Unfortunately Wednesday is not tough enough to resist the intrusion of reality into her dream through the 'granite shaft' of Bellister's personality (260). His reasoned arguments, his pressure on her to marry him and return to reality, start to stifle Wednesday and diminish her fantasy. Rather than relinquish the dream, she lets herself drown in the harbour. The artist, dreamer and rebel retains the integrity of her vision and her personality in one last, defiant, tragic act.

Lee, John A.

John A. Lee was born in Dunedin in 1891, the son of a vagrant, Romney father and a hardworking Scots mother. Alfredo Lee deserted his family when Lee was a baby and Lee grew up in poverty. This resulted in the growing Lee becoming a thief and he was sentenced to Burnham Industrial School in 1906. These experiences are at the core of his autobiographical novels Children of the Poor (1934) and The Hunted (1936). The more purely autobiographical Delinquent Days (1967) focuses on his attempts to escape from Burnham, and his life as a swagger. In World War I Lee lost his left forearm and was awarded the DCM. After returning to New Zealand he joined the Labour Party and served as an MP. During this time he sought to improve housing, education and living conditions. Expelled from the Labour Party in 1940 for attacking Prime Minister Michael Joseph Savage, Lee founded the Democratic Labour Party but was never re-elected. He continued to circulate his views through journals such as John A. Lee's Weekly. His socialist political views are also articulated in Socialism in New Zealand (1938). Lee's political position is perhaps best summed up in his famous rejoinder to the accusation on the occasion of his expulsion from Labour that he was incapable of loyalty because he was from the gutter: 'So long as there is one person down in the gutter, then, my God, I am there too.' (Olssen: 159). In the 1950s Lee became a successful Auckland bookseller and continued his career as a novelist and political commentator. He died in 1982. Lee's Simple on a Soap-Box (1963) highlights the shape and purpose of his political career, while Erik Olssen provides a biographical and political study of Lee in John A. Lee (1977). This bibliography focuses on Lee's two early fictional accounts of his childhood. Erik Olssen writes that Lee's fictional 'goal was to educate his contemporaries and shatter the old culture' (70).

Children of the Poor, 1934 (Christchurch, Whitcoulls, 1979)

Set in Dunedin, Children of the Poor is damning of Puritan conformity and hypocrisy. Lee's fictional self, Albany Porcello is an isolated outsider. He and 
his family are alienated from society by reason of their poverty. Albany is aware that his family are 'outcasts in the city of steepled kirks. Richard Seddon, New Zealand's Premier, called New Zealand 'God's Own Country' and told of the plenty there would be for all. But we were always poor' (22). As the victims of society's moral judgements and capitalist greed the Porcellos are used by Lee to expose Puritan hypocrisy and stinginess. He also argues that poverty is the parent of crime. Both Albany's sister and mother sell their bodies to relieve the poverty of themselves and their family. Society judges and dismisses them; the child as a 'Chine whore', the mother as a fallen woman (209). Albany points the finger firmly at the society that makes such transgressions inevitable:

Morality is so easy when one resides amid plenty; that is conventional morality, which frequently is only scientific avoidance of consequences... I see my mother selling herself to keep us clothed and fed and to pay the rent. Does it matter what society's verdict was? What else was the drudge to do? (95).

In a similar fashion, society is quick to label Albany a thief, failing to realise that he steals because he is poor. For Lee, the crimes of the Porcellos are the result of 'economic determinism' (118). The novel ends with Albany being hunted down. The laws of society state that the transgressor must be punished, the fugitive must be caught, the rebel must be disciplined. Lee sees this pattern of chastisement and discipline as a process of containment, of repression, of annihilation.

The Hunted (London: T. Werner Laurie, 1936)

The Hunted is the sequel to Children of the Poor. Condemned to Burnham Industrial School because of his thieving, Albany resolves to take every opportunity to run away. As the title of the novel suggests, the novel revolves around a series of escapes and captures. In Delinquent Days (1967) Lee recalls that 'the hell of being hunted was modest compared to the hell of witless immobility. Some boys refused to be sheep. Many splendid lads had no alternative to outlawry' (6). Escape may bring physical deprivation and the terror of capture, but Lee argues that it is better than the brutality and sadism of Burnham. The correction school is ruled by the Manager, a thug with an unnatural obsession with sex. Delighting in brutal floggings of those in his care, he has the hypocrisy to emerge smiling from a bout of physical punishment to urge the Burnham boys to sing 'Glory to thee, my God, this night / For all the blessings of the light...' (32). Lee further exposes the Manager's hypocrisy through his depiction of the Burnham sex parades. The 
Manager's avowed purpose may be to stamp out vice, but his preoccupation with 'perversion' and 'unclean[liness]' are evidence that he himself has the mind of a sewer $(65,68)$. Lee protests at the way the Manager distorts something beautiful into something ugly:

There was no word about parenthood. Sex was slimy. The human family was created out of a sewer...So it was that as manhood was dawning and stirring in the physical and emotional depths of Albany Porcello, he was emerging from purity lectures which left him convinced that the journey from boyhood to manhood was a progression from wholesomeness to rottenness (70-1).

The representatives of authority in The Hunted, particularly the Manager, are narrow, self-righteous and hypocritical - damning portraits of a corrupt Puritan society. In contrast, boys such as Albany, who are labeled as deviants, are commended by Lee for their spontaneity, generosity and anarchic, irrepressible spirit.

\section{Mander, Jane}

Jane Mander is central to the anti-Puritan tradition in New Zealand literature. She describes Puritanism as an 'awful disease' which needs to be 'cured' in The Story of a New Zealand River (27) and provides a detailed description of the deficiencies of Puritan New Zealand in her essay 'New Zealand Novels: The Struggle Against Environment':

The mumbo-jumbo of the herd still prescribes what most of our people shall think. We have flourishing in this country all the old hangovers of intolerance, narrow respectability, fear of criticism, lack of moral courage, and, in spite of recent able and heroic efforts on behalf of freedom of speech, we really have no spiritual freedom worth the name. (APL NZ MS 535)

Mander was born in 1877, a third generation New Zealander. Her father, Frank Mander, was a successful entrepreneur, logging kauri and building roads and tramways into the Northland bush. Constant shifts in location disrupted Mander's education and prevented her from attending secondary school. Working as a pupil-teacher she eventually qualified as a teacher, but was able to pursue her dream of writing when her father moved to Wangarei and purchased the Northern Advocate. For the next decade journalism dominated her life. In 1912, after a bitter struggle with her parents, Mander left 
New Zealand to attend university in New York. Her first novel, The Story of a New Zealand River, was published in 1920. The Passionate Puritan was published the following year and, after a shift to London, Mander produced four more novels. Her work was praised by the British and American press, but New Zealand reviewers were more critical, attacking her for undermining 'good public morality' with her 'sex-obsessed' fiction (Reviews of Novels, APL NZ MS 535). Mander replied by expressing her determination to stand by the integrity of her artistic vision, 'to be honest, and to be loyal to [her] own experience' ('The Author's Reply to Critics' APL NZ MS 535). After a struggle to makes ends meet Mander returned to New Zealand. Her family's promise of peace and money to aid her work never eventuated and she became the unpaid drudge of her ageing father and ill sisters. While these New Zealand years until her death in 1949 provided support and encouragement for budding New Zealand writers, such as Monte Holcroft and Frank Sargeson, she was plagued by a sense of frustration and wasted talent. In the autobiographical fragment 'Preface to Reminiscences' she writes: 'I have always been far more interested in other people's work than my own. That is why I have been a very minor novelist... In that I have been entirely frustrated.' (APL NZ MS 535).

Allen Adair, ed. and intro. by Dorothea Turner, 1925 (Auckland: Auckland University Press, 1984)

Allen Adair, Mander's fourth novel and last fictional evocation of New Zealand, is deeply pessimistic about the possibility of individuals successfully rebelling against Puirtanism. Auckland is the source of a suffocating Puritan materialism. The hero, Allen Adair, feels 'stifled' and 'trapped' by his family's determination to fix him in a respectable, prosperous mould $(40,3)$. He successfully seeks freedom in the peace and open horizons of the New Zealand north. Allen's tragedy is that having found what satisfies him he proceeds to destroy it. By marrying Marion Holt he imports all that he has escaped to the gumfields. Marion is snobbish, acquisitive, prudish and incapable of giving Allen the space he needs. She nags him about his friendship with Geraldine Ashbury and urges him to find a more respectable occupation. Allen is virtually defenceless against this fresh invasion of Puritanism. He makes no attempt to change Marion and seems incapable of decisive action, except when he stops sleeping with Marion after her vulgar insinuations about Geraldine. Eventually Allen gives in to the web of duties which entangle him, returning to Auckland. Tragically this fails to satisfy Marion's 'hunger' for Allen love and he himself is quickly enmeshed in the life he despises; the clubs, the parties, the visitors (175). The forces of bourgeois Puritanism are ultimately triumphant in Allen Adair. The north, with its promise 
of sanctuary and hope of freedom, is left behind. Allen is left with a 'sense of futility' (175). Once more 'the world of facts and the world of dreams [are] far apart' (175).

The Besieging City: A Novel of New York (London: Hutchinson, 1926)

In The Besieging City Mander critiques the Puritan perception that marriage is the goal that all women should seek. The heroine, Christine Mayne, is steadfastly independent, the first woman to break into an elite intellectual New York journal. She refuses to be cowed by poverty and loneliness and has a decidedly modern attitude to sex. Christine enjoys her liaison with Gerry Lloyd but refuses to marry him. She 'simply cannot see [her]self in that environment', preferring to maintain 'absolute freedom' $(174,172)$. For Christine, marriage is a threat that has the potential to undermine her autonomy and selfhood. She declares that she must 'liv[e] alone' in order 'to keep intact' (232). Her bohemian attitude towards relationships means that she chooses the 'adventure' of an affair over the 'habit' of marriage (232). The novel ends with Christine leaving New York, resolutely alone. Mander emphasises that domesticity and child bearing are not the only options for women. She pays tribute to women like Christine (and herself) who prefer to dedicate themselves to the complexities and difficulties of a career.

The Passionate Puritan (London: John Lane, 1921)

The Passionate Puritan is set against a backdrop of early twentieth century male enterprise. Jack Ridgefield is modelled on Mander's brother and he represents all that is admirable about the colonial inheritance: strength, determination, dedication. This 'extraordinarily pure male' uses his 'strength' and 'confidence' to engineer a railway and build a dam in order to make access to the Northland timber forests easier $(209,18)$. However, while Mander admires those shaped by the Puritan work ethic, the novel is fundamentally anti-Puritan. Puhipuhi is 'almost a perfect specimen of bourgeois respectability' in which conformity and moral orthodoxy is the guiding principle (42). The heroine, Sidney Carey, tries unsuccessfully to rouse the village from its complacency and narrow gentility: '.... she had only to suggest a new way of doing some familiar thing, such as bottling tomatoes, and everyone in the place would at least have tried it. But if she had suggested a new way of thinking about God as force, or sin as defective education, they would not have followed her an inch' (63). While Sidney sees herself as an enlightened prophet crying in the wilderness, the narrative action revolves around her discovery that her own attitude towards sex is Puritan rather than emancipated. She condemns Arthur Devereux for his previous marriage and his liaison with Mana, using her chastity as a weapon against 
him. Mander insists that her heroine needs to lose her sexual inhibitions. Not until Sidney accepts that chastity is 'merely a superficial command that no one with a particle of character considered' and that companionship and humour are more vital in a relationship than fidelity, can her passions be released (213).

Pins and Pinnacles (London: Hutchinson, 1928)

Set in London, Pins and Pinnacles reinforces the point made in The Besieging City that marriage is not the automatic guarantor of happiness for women. The heroine, Mirabel Heath, experiences the trauma of an unwanted and unhappy early marriage. Her husband has a sexual disease that results in the birth of a deformed child whom Miriam is never allowed to see. The narrative action takes place years after this tragedy. Miriam has become a successful artist and is content to live alone. The melodramatic, contrived plot revolves around the love that grows between Miriam and the misogynist publisher, Paul Daley, who lives next door. Paul's shellshocked childhood friend is jealous of Miriam and tries to kill her, afterwards committing suicide. In spite of her unhappy marriage Miriam decides to marry Paul, confident that two independent individuals who respect each other's need for privacy can have a satisfying, loving relationship. Lydia Wevers describes the mature Miriam as the New Woman, independent, mobile, professional, metropolitan, who chooses marriage only when she is ready to, and who is free from the dictates of orthodoxy' (252).

The Strange Attraction (London: John Lane, 1923)

Valerie Carr, the heroine of The Strange Attraction, is the embodiment of Mander's feminism and anti-Puritanism. She is independent, renouncing the easy path of wealth and respectability offered by her Remuera family in order to pursue her career as a journalist in Dargaville. Puritanism is endemic in provincial Dargaville, symbolised by the town's deep disapproval of Dane Barrington because he has figured as correspondent in a divorce case. Likewise, his house with its 'suggestion of silken rakishness' offends the Puritan sensibilities of Dargaville (50). It is a 'glimpse of sin' to those 'brought up on Victorian antimacassar, wool work, and the aenemic props of spidery furniture and mission art' (51). In contrast, Valerie's anarchic spirit responds to Dane. Her contempt for convention is seen in the way in which she smokes, drinks beer and sits on the hotel balcony in her bloomers. Likewise, she dismisses Puritan attitudes towards sex. Both Valerie and Dane have sexual histories. Mander insists that this is irrelevant to their relationship. What matters is their respect and love for one another. The Puritan concept of 'ruin' makes Valerie laugh (229). Indeed, so far is Valerie from the Puritan belief 
that marriage is the only pure outlet for sexual feeling that she resents having to marry Dane. She takes off her ring as soon as the marriage is complete, bitter that 'this is all that stands between morality and immorality in the eyes of this crazy world', and insists on keeping her job (218). Ultimately, much as she loves Dane, Valerie's work and independence are stronger than her passion. At the end of the novel she leaves him to travel to Europe where the prospect of war looms, conscious that this is a 'forward movement' (298). Mander emphasises that relationships play only a part in the complex drama of the life of a fully rounded woman.

The Story of a New Zealand River, afterword by Dorothea Turner, 1920 (Auckland: Godwit Publishing, 1994)

Mander's first novel, set against the backdrop of kauri felling in the far north, is her most optimistic. In The Story of a New Zealand River she draws attention to the 'awful disease' of Puritanism, but is confident that the 'cure' of modernism, feminism, socialism and atheism will purge the Puritan taint from New Zealand society (27). The heroine of the novel, Alice Roland, has retreated into the Puritan respectability of her upbringing after an affair as a teenager resulted in pregnancy and disgrace. Her 'whole life had been a reaction from the pitiful mistake of her youth...one long support of the respectabilities, all the more fierce because she had suffered so much from her own failure to observe them' (244). She marries Tom Roland in order to regain security and respectability and submits to his desires and demands as a suitable penance. Alice's Puritan judgementalism and inhibitions are gradually undermined when she comes to live in Tom's mill community by the Kaipara River. The natural environment, particularly the ebb and flow of the tidal river, causes her 'to question the verities' (83). In the small bush community she has to accept people for the job they do, not their rank, just as she has to accept help during pregnancy and illness. The people she encounters in Pukekaroro also help to 'cure' Alice's Puritanism (27). The English settler, Mrs Brayton introduces Alice to Voltaire, Schreiner and Wilde. David Bruce awakens Alice's dormant passions and exposes her moral orthodoxy as merely 'organised prudery and aenemic chastity' (51). Asia, both as child and woman, forces her mother to challenge accepted beliefs and attitudes. The mature Asia is Mander's prototype of the ideal 'new woman': a feminist, a socialist, a well-educated career woman who is financially independent, a sexually liberated agnostic. Alice never reaches this level of liberation, but is slowly reborn as 'a thinking, independent, generous woman capable of response' (Stevens: 37). The strength of the novel lies in Mander's psychological depth, her awareness that transformation is a slow, painful, frequently incomplete process. 


\section{Morton, Frank}

Born in England in 1869, Frank Morton emigrated with his family to Sydney at the age of 16. After early journalistic experience in Singapore and Calcutta, he became a well known Australian journalist. In 1905 Morton moved to Dunedin to work on the Otago Daily Times. A move to Wellington two years later saw a shift to freelance journalism and involvement with C. N. Baeyertz's outspoken monthly journal, the Triad. Morton wrote most of each issue, including poetry, fiction, gossip and book reviews, using both his own name and a variety of pseudonyms. Dennis McEldowney writes that Morton consistently 'opposed conservative respectability and whatever he thought of as humbug and cant' (351). Morton's desire to shock readers is seen in his anti-Puritan, protofascist political pamphlet The Angel of the Earthquake. He also published two volumes of poetry while in New Zealand, Laughter and Tears (1908) and Verses for Marjorie (1916). In 1914 Morton returned to Sydney where he continued to be involved with the Triad and published several volumes of love poetry. He died in 1923.

The Angel of the Earthquake (Melbourne: Atlas, 1909) Morton's political fable The Angel of the Earthquake viciously attacks Puritan narrowness and repressiveness. His anti-Puritanism leads him to oppose women's suffrage, which he blames for the prevalence of Puritan legislation. The hero of the novella scoffs at the irrelevancy and hypocrisy of Christianity. Religious faith is to him a jest, church services 'a survival as apt as the pterodactyl' and the congregation mostly 'callous sharks and solid hucksters better dead' (13-14). The earthquake visited on Wellington on Christmas day 1910 is seen by Morton as a necessary cataclysm to purge New Zealand from the taint of Puritan religion, Puritan morality and Puritan politics. He writes that through the earthquake and the lawlessness that followed it New Zealand 'learned to despise the fallacies to which it had clung' (51). Christianity and social morality do not stand the test of the earthquake. They are incapable of quelling the rioting and are exposed as 'deepbased in hypocrisy and infamous prejudice' (40). In the new order that emerges Puritanism plays little part. Morton hails the new era as 'the dawn of individual liberty' (52). This may be an apt description of the greater religious freedom, but it is completely inappropriate when related to Morton's political vision. Peace and order are eventually restored to New Zealand by the Corps, a group of self-appointed, armed vigilantes. Their leader, Andrew Waterton, is christened 'the Angel of the Earthquake' for his ruthless execution of rapists, murderers and looters. 
The proto-fascist, authoritarian state which Waterton controls may be 'the triumph of the individual over the mob', but it has unpleasant overtones of Nazi Germany and fascist Italy (52).

\section{Mulgan, John}

Mulgan's forebears settled in Katikati in the 1870s, part of George Vesey Stewart's vision of an Ulster plantation. However, he never defined himself as either Irish or Protestant. The lure of England and the world of letters, not Ireland, was strong in Mulgan and his world view was shaped by socialism, not religion. Born in Christchurch in 1911, Mulgan spent his adolescence in Auckland. He was part of a literary family. His father Alan Mulgan was a novelist and essayist and his mother Marguerite was a musician and one of the first female graduates of Auckland University College. Mulgan studied at Auckland University, where he was involved in student journalism and politics. After the Auckland riots his political views became more socialist. In 1933 he departed for England. After graduating at Oxford with a first class degree Mulgan began a publishing career with Oxford University Press. He dabbled with Communism, explaining in Report on Experience (1947) that he believed it 'offered something of a future, a programme for builders', but retained doubts about 'a political system that embraces men so willing to escape from themselves, that offers this easy answer and refuge from decision' $(117,32)$. Mulgan was actively involved with the Left Book Club, editing Poems of Freedom for Victor Gollancz. After serving throughout World War II Mulgan took his own life in 1945.

Man Alone, 1939 (Auckland: Longman Paul, 1967)

In Man Alone Mulgan makes his complaint against Puritan society through the experiences of his marginalised hero Johnson. Immigrating to New Zealand after World War I, Johnson is at first an alien by reason of nationality. However, he soon realises that the differences between his outlook and the New Zealand philosophy are far deeper and far less eradicable than his foreignness. Unlike almost all the New Zealanders he encounters he has 'no ambition' and very little desire for ownership of property (21). He wants a life of freedom, the ability to 'go about and get work, and stop when he wants to, and make money when he wants to, and take a holiday when he feels ready for one...(35-6). This holiday spirit - the ability to see beyond the cycle of work, the willingness to spend money on personal enjoyment - makes Johnson an outsider in a materialistic land. He is also aware that the struggle to wrest prosperity from the land, particularly during the Depression years, is 
frequently futile and soul-destroying. The tragedy of Stenning's death illustrates this point. Johnson blames not himself, Rua, or Stenning for the tragedy, but the draining obsession with the land: 'It came with working away there on that farm, just the three of us, and no pay...You couldn't get away. You couldn't do anything but go on working...It wasn't any life...' (182). Mulgan attacks the capitalist structure of society, pointing out that in such a society it is always the workers, not the land owners and company directors, who pay the biggest economic and social cost during times of hardship. The kind of protest seen in the Queen Street riots is the inevitable result of unemployment and poverty. Johnson declares: 'I've worked hard all my life... and been paid damn all. If fellows like me make more trouble now than they used to it's because they've got more sense' (182). Mulgan is also concerned with the way in which the capitalist-Puritan ethos of New Zealand society during the Depression years creates a society of isolated individuals. Johnson's search, throughout Man Alone, is for a sense of community and belonging. He experiences a brief moment of common purpose during the Queen Street riots and searches for this sense of 'men moving, making something together' when he departs for the Spanish Civil War at the end of the novel (196). For most of the time, however, Johnson is aware that 'a man spends too much time alone' (205).

\section{Satchell, William}

Influenced by Huxley, Mill and Spencer, Satchell was a sceptic particularly opposed to the concepts of a personal God, the immortality of the soul and the literal accuracy of the Bible. He was also a devotee of science, Darwin's The Origin of Species helping to shape his evolutionary beliefs. Satchell was born in England in 1860. After studying in Germany he worked in his father's publishing business. Financial difficulties and poor health were behind his decision to immigrate to New Zealand in 1886. He first settled in the Hokianga, where he met his wife Susan, and then moved to Auckland where he worked as a journalist, a secretary, an accountant and the editor of his paper The Maorilander. Satchell was constantly plagued by financial difficulties. His four novels were published between 1902 and 1914 . While Satchell's first two novels were well received, the Athenaeum describing The Toll of the Bush as 'a colonial novel of remarkable merit and distinction', they raised little interest in New Zealand (Wattie: 477). Published on the eve of World War I, The Greenstone Door with its anti-war theme was not well received. Near the end of his life Satchell said of The Greenstone Door: 'Had I been given any encouragement, it would have been my fourth book, not the 
last' (Wattie: 477). Before his death in 1942 Satchell was to see a growing interest in and the republication of his final novel. This bibliography will focus on two historical novels with an anti-Puritan flavour: The Toll of the Bush and The Greenstone Door. Satchell also wrote The Land of the Lost (1902), a melodramatic tale of success and failure in the gumfields of Northland, and The Elixir of Life (1907), a science fiction novel about the discovery of a miraculous elixir which will eliminate disease.

The Greenstone Door, 1914 (Auckland: Whitcombe and Tombs, 1935) The Greenstone Door is both a bildungsroman tracing the growth and development of Cedric Tregarthen and a historical novel focusing on contact and tensions between Maori and Pakeha in New Zealand. Cedric, the adoptive son of the trader Purcell, grows to maturity among the Ngatimaniapoto. This gives him an awareness of Maori culture that makes him critical of Pakeha land hunger and racist attitudes. Drawn to the 'civilised' world of the arts and the comforts of life represented by Lady Wylde and Governor Grey, Cedric nevertheless cannot abandon his New Zealand family and roots to travel to England. As war breaks out between Maori and Pakeha Cedric's loyalties tear him in two. He can fight for neither side, and the deaths of his friend Rangiora in battle and his foster father Purcell at the hands of a firing squad tip him into madness. The love of Helnora Wylde cures him, but Cedric remains a marginalised outsider in post-war New Zealand. Satchell is similarly pessimistic about the fate of Maori. For all his criticism of settler greed, Satchell sees Pakeha progress as inevitable. His Darwinist beliefs lead him to think that settlement will necessarily have a 'fatal impact' on Maori and the novel is in many ways Satchell's lament for what he sees as the tragic disintegration of Maori society. A significant feature of the novel, both in terms of its critique of Puritanism and its reshaping of colonial history, is the way Satchell, in spite of his evolutionary beliefs gives Maori a voice. He is aware that while missionary activity offered many educative advantages to Maori it also undermined traditional culture. Te Huata uses the Christian metaphor of the light to demonstrate this, speaking of the moth that is destroyed by the flame and declaring: '...go not forwards into the light, lest as the moth you be consumed, and it is asked of the Maori, where is he?' (95). Likewise, Purcell looks with scepticism on missionary crusaders determined to 'carry the rongo pai into dark places' (75). He is an enlightened agnostic who critiques Pakeha racism, his scientific knowledge making him aware that 'the pigmented skin is man's armour-plate against excessive sunlight' not a sign of ignorance and savagery (253). He tells Cedric: 'I am colour-blind...There was a time in the history of this planet when the white man was the savage and the swarthy man the person of intellect. It will come again...' (254). This evolutionary, 
cyclical philosophy offers a different interpretation of history to the Puritan tenets of absolute truth and predestination and suggests that the Maori defeat in the New Zealand wars needs to be viewed against a larger historical backdrop.

The Toll of the Bush, ed. and intro. by Kendrick Smithyman, 1905 (Auckland: Auckland University Press, 1985)

The Toll of the Bush articulates most fully Satchell's anti-Puritan thinking. His scepticism is revealed both in his critique of the religious practices and character of the revivalist preacher Fletcher and in his creation of an intelligent, agnostic hero. Fletcher is arrogant, cold, and unscrupulous. Major Milward questions: ' . . is there anything about him beyond what he says? If one wanted a fiver, would it be obtainable there sooner than elsewhere? If one needed sympathy, would it come more reliably...? No, By God!' (49-50). The preacher is also a hypocrite who uses the platform to make vindictive, unfounded attacks against Geoffrey Hernshaw in an attempt to win Eve Milward. Satchell demonstrates that religious fervour is no guarantee of integrity. Indeed, it is dangerous, because it raises expectations of moral worth among the undiscerning. Character, not cloth, is the yardstick by which Satchell measures people. His hero is an agnostic whose ideas are shaped by Darwin. Geoffrey describes Christianity as 'the old, worn track' that has been superceded by the new 'formed road' of scientific knowledge'. Reason and science will ultimately strip away old superstitions and leads humanity to 'the fountain of Truth, the Absolute' (96-7). Significantly, Eve is ultimately united with Geoffrey. Fletcher's death and the union of the lovers in the bush fire may be melodramatic and contrived, but the events have symbolic value in the battle between faith and scepticism. Geoffrey's triumph is also the triumph of reason and science over a flawed religion.

\section{Wardon, Reve}

My research in the Turnbull and National libraries has failed to uncover any of Wardon's personal details. MacPherson's Gully is his only published work and its long sub-title, A Tale of New Zealand Life: Containing Some Views of the Social Outlook from the Proletarian Standpoint, is suggestive of socialist leanings. This is confirmed by the content of the novel.

MacPherson's Gully: A Tale of New Zealand Life: Containing Some Views of the Social Outlook from the Proletarian Standpoint (Christchurch: Simpson and Williams, 1892) 
In MacPherson's Gully Wardon uses the Puritan genre of the morality tale to communicate his anti-Puritan message. All the classic components of the salvation novel are present at the opening of the tale. Alick and Jeanie Spencer arrive in New Zealand from Scotland determined to build a prosperous future for themselves and their children. Their industry and faith results in success and even the setback of Alick losing his job seems to be a blessing in disguise when he discovers gold. However, Wardon employs the conventions of the moral tract only to invert them. His is a parable of the futility of work and faith, not of the rewards of virtue. Tragedy rather than prosperity, death rather than improved life is meted out to the hero. At the point of realising his ambition 'to be the owner and occupier of a freehold farm', Alick learns that his children have died of diptheria and that his wife has gone mad and is committed to Sunnyside (26). He loses his money and drowns crossing a river. Wardon ends with a savage attack on the Puritan ethics his hero has trusted, declaring that it is his 'mature conviction that there is neither truth nor justice in the universe of God' (47). His anti-Puritan views are shaped by socialist beliefs. Mac's anti-capitalist speech halfway through the novel makes this clear. He emphasises that the lives of working people such as Alick are 'a mere funeral procession to the grave', distinguished not by hope and opportunity but by a 'heritage of despair' (19). Mac urges the people to throw off the shackles of religion and capitalism to create 'a new Order more permanent, because more equitable than the present, in which the selfish individualism now rampant in society will give place to a loyal regard for the common weal' (21).

\section{WORKS CITED}

Baxter, James K. Aspects of Poetry in New Zealand. Christchurch: Caxton, 1972.

Body, Gillian and Jacqueline Matthews, eds. Disputed Ground: Robin Hyde Journalist. Wellington: Victoria University Press, 1991.

Bolitho, Hector. My Restless Years. London: Max Parrish, 1962.

Chapman, Robert. 'Fiction and the Social Pattern'. Essays on New Zealand Literature. Ed. Wystan Curnow. Auckland: Heineman, 1973.

'C. J.' Review of A Pagan's Love. The Sydney Bulletin 8 June 1905. Alexander Turnbull Library MS 13/19/1, 23 Sept. 1987.

Clyde, Constance. Autobiographical Fragment. Australasian Autobiography. Alexander Turnbull Library MS 0095. 
Clyde, Constance. 'The Literary Woman'. The Sydney Bulletin 6 September 1902. Alexander Turnbull Library MS 13/19/1, 23 Sept. 1987.

Devanny, Jean. Point of Departure: The Autobiography of Jean Devanny. Ed. Carole Ferrier. St Lucia, Queensland: University of Queensland Press, 1986.

Hyde, Robin. A Home in this World. Auckland: Longman Paul, 1934.

Hyde, Robin. Letter to J. H. Schroder, 1936. Alexander Turnbull Library MS 0280.

Jones, Lawrence. 'The Novel'. The Oxford History of New Zealand Literature. Ed. Terry Sturm. Auckland: Oxford University Press, 1998.

Jones, Lawrence. 'Puritanism'. The Oxford Companion to New Zealand Literature. Ed. Roger Robinson and Nelson Wattie. Melbourne, Auckland: Oxford University Press, 1998.

Lee, John A. Delinquent Days. Auckland: Collins, 1967.

McEldowney, Dennis. 'Morton, Frank'. The Dictionary of New Zealand Biography, Volume 3: 1901-1920. Auckland: Auckland University Press, 1996.

McLauchlan, Gordon. The Big Con: The Death of the Kiwi Dream. Wellington: G. P. Publications, 1987.

McLauchlan, Gordon. The Passionless People. Auckland: Cassell New Zealand, 1976.

Mander, Jane. 'The Author's Reply to Critics'. The Auckland Star 9 Feb. 1924. Auckland Public Library NZ MS 535.

Mander, Jane. 'New Zealand Novels: The Struggle Against Environment'. The Press 15 Dec. 1934. Auckland Public Library NZ MS 535.

Mander, Jane. 'Preface to Reminiscences'. Auckland Public Library NZ MS 535.

Mander, Jane. Reviews of Novels 1920-1938. Auckland Public Library NZ MS 535.

Moffat, Kirstine. 'The Puritan Paradox: The Puritan Legacy in the Intellectual, Cultural and Social Life of New Zealand, Focusing Primarily on the Works of Novelists Writing Between 1862 and 1940'. Unpublished Ph.D thesis. Victoria University of Wellington. 1998.

Mulgan, Alan. ‘Edith Searle Grossmann Pioneer'. Art in New Zealand 3.2 (1931). 
Mulgan, John. Report on Experience. 1947, Auckland: Blackwood and Janet Paul, 1967.

Olssen, Erik. John A. Lee. Dunedin: University of Otago Press. 1977.

Pearson, Bill. 'Fretful Sleepers'. Landfall 6 (1952).

Stevens, Joan. Introduction. A South-Sea Siren. George Chamier. 1895, Auckland: Auckland University Press, 1970.

Stevens, Joan. The New Zealand Novel. Wellington: Reed, 1966.

Wattie, Nelson. 'Adams, Arthur'. The Oxford Companion to New Zealand Literature. Ed. Roger Robinson and Nelson Wattie. Melbourne, Auckland: Oxford University Press, 1998.

Wattie, Nelson. 'Satchell, William'. The Oxford Companion to New Zealand Literature. Ed. Roger Robinson and Nelson Wattie. Melbourne, Auckland: Oxford University Press, 1998.

Wevers, Lydia. 'Pioneer and Feminist: Jane Mander's Heroines'. Women in Society. Ed. Phillida Bunkle and Beryl Hughes. Auckland: G. Allen and Unwin, 1980. 